\title{
Vida real e forma-de-vida: uma reflexão a respeito da relação entre arte e vida em Giorgio Agamben e Villa-Lobos
}

\author{
Lurian José Reis da Silva Lima (Universidade Estadual do Paraná, Curitiba, PR, Brasil) \\ lurianlima@gmail.com
}

\begin{abstract}
Resumo: A relação entre arte e vida é, para o Giorgio Agamben, uma questão poética tanto quanto filosófica e política. O que se propõe neste artigo é uma reflexão que vincula as ideias do filósofo italiano sobre tal questão e o modo como a vida e a obra do compositor brasileiro Heitor Villa-Lobos são retratadas em sua primeira e principal biografia. A tese em torno da qual se constrói tal reflexão é a de que o modo como a vida e a obra de Villa-Lobos aparecem unidas nessa biografia reflete uma postura político-artística que não pode ser negligenciada, pois nasce do profundo desejo do compositor de fazer-se singular ou, nos termos de Agamben, de não existir senão como uma forma-de-vida. Palavras-chave: Giorgio Agamben; Villa-Lobos; Arte e vida.
\end{abstract}

Real life and form-of-life: a reflection on the relation between art and life in Giorgio Agamben and Villa-Lobos

Abstract: The relation between art and life is, for Giorgio Agamben, a poetic question as much as philosophical and political. This paper proposes a reflection that links Agamben's ideas on this subject and the way in which the life and the work of the Brazilian composer Heitor Villa-Lobos are portrayed in his first and most important biography. The thesis on which such reflection is constructed is that the way in which Villa-Lobos's life and work appear united in this biography reflects a political-artistic posture that should not be neglected, because it comes from the composer's deep desire to become singular or, in Agamben's terms, to exist only as a form-of-life.

Keywords: Giorgio Agamben; Villa-Lobos; Art and life

Como pensar a relação entre arte e vida? De que maneira e em que medida a vida de um artista se diz em sua obra ou sua obra se diz em sua vida? No período em que surgem os compêndios de música erudita brasileira, entre as décadas de 1920 e 1980 - quando a musicologia do país estava interessada, sobretudo, em pensar e descrever um longo movimento teleológico que levasse à ascensão de uma música "verdadeiramente nacional" - essas questões não entram em pauta senão, talvez, em um livro. Trata-se da primeira biografia do mais conhecido músico erudito do país: Heitor Villa-Lobos: compositor brasileiro, de autoria do diplomata e musicólogo Vasco Mariz (1983). A biografia tem, entre suas metas, a de estabelecer elos entre o vivido e o "musicado" na trajetória de Villa-Lobos, ainda que, para tanto, fosse preciso criar uma narrativa fantástica, repleta de exageros, imprecisões e invenções que vêm sendo criticados e desconstruídos por estudos mais recentes.

Não deixa de ser interessante, contudo, pensar a respeito da excepcionalidade que essa narrativa representa na musicologia brasileira. A que se deve a tentativa absolutamente incomum de vincular sem frestas a vida à obra, mesmo que para tanto fosse necessário inventar boa parte dessa vida? Dentre as várias possibilidades de abordagem dessa questão, gostaria, aqui, de explorar uma via pouco usual: a da filosofia. Parece-me que esse relato fabuloso encerra uma postura político-artística em relação ao mundo que não pode ser descartada, pela pretensão atual (e legítima, bem entendido) da pesquisa em música de revelar a "realidade" da trajetória de Villa-Lobos. Tal suspeita é o que move este trabalho. Ela nasce da "convivência" que tive com o compositor nos últimos dois anos - ao longo da pesquisa de mestrado que empreendi nesse período (LIMA, 2017b) - e da leitura do filósofo Giorgio Agamben. Nas páginas que se seguem, procuro traçá-la em linhas mais vigorosas.

\section{A arte da palavra e a vida}

Em O ditado da poesia, um texto escrito na década de 1990 como introdução a Poe- 
sie della fine del mondo, de Antonio Delfini, e recentemente publicado na coletânea intitulada Categorias italianas, o filósofo Giorgio Agamben (2014) se propõe a discutir a relação entre arte e vida num terreno que, se não é propriamente musical, guarda com a música vínculos históricos bem conhecidos: a poesia. E, para Agamben, essa questão se situa no centro de um problema especialmente caro à sua quête filosófica: os estatutos da linguagem e da vida na cultura ocidental:

O que significa, para um vivente, falar? [...] Vida e palavra constituem uma unidade bem articulada ou, ao invés, permanece aberta entre elas uma diferença que nem a existência individual nem o desenvolvimento histórico da humanidade conseguiria por inteiro colmatar (AGAMBEN, 2014, p. 103)?

Segundo Agamben, “o terreno sobre o qual tal problema [a relação linguagem-vida] poderia ter sido corretamente colocado” (p. 103) pela crítica literária e pela estética ainda se esconde sob os escombros do "canteiro de obras" das duas disciplinas que primeiro se ocuparam das questões acima anunciadas: a teologia e a psicologia. É, com efeito, a ausência de reflexão sobre uma herança teológica o que impede que a relação linguagem-vida seja tomada de fato como "o lugar mais próprio da obra poética", tanto pela crítica literária quanto pela "moderna ciência do texto" (a referência feita aqui é a Jacques Derrida). Trata-se do "pressuposto puramente teológico" da "demora do logos na arché, ou seja, o estatuto absolutamente primordial da linguagem" (p. 104). Se, no desenvolvimento de suas análises, Derrida se afasta da redução psicológica do texto literário a um "significado absoluto" distante do próprio texto, o seu apego ao significante e à letra o desvia daquilo que, para Agamben, parece constituir o cerne de toda experiência poética, isto é, o fato de que a palavra, a linguagem humana, está sempre em íntima relação com a vida.

Agamben não pretende, nos limites do ensaio do qual falamos aqui, reformular o problema do qual se ocupa: quer, antes de tudo, revelar, mesmo que de maneira sumária, as camadas daquele terreno pouco explorado onde tal formulação poderia ser feita de maneira adequada. Para tanto, o filósofo lança mão do procedimento investigativo mais característico de sua obra: uma arqueologia, desta vez para resgatar a origem e os desvios das reflexões acerca da relação linguagem-vida no bojo de determinadas vertentes do pensamento ocidental, para as quais nem a crítica literária nem a "moderna ciência do texto" haviam olhado com a merecida atenção. Vê-se bem que não se trata, aqui, simplesmente de datar tais reflexões, de dar-lhes um "lugar" histórico: o sentido da arqueologia agambeniana é trazê-las à luz em sua perene atualidade, enquanto rastros ignorados da história nos quais se fundamenta o olhar contemporâneo do filósofo sobre o tema em questão.

O primeiro desses rastros Agamben encontra no prólogo do Evangelho de João, no qual a vida e a palavra (os termos gregos zoé e logos) se cruzam na seguinte fórmula: "Tudo foi gerado por ele [o Logos] e sem ele nada foi gerado daquilo que foi gerado; nele estava a vida, e a vida era a luz dos homens" (p. 104). O filósofo lembra, entretanto, que essa passagem do texto seria alterada no século IV, e a vida, que ali aparecia como aquilo que morava no logos antes de toda criação, desponta agora como aquilo que se gera no logos, que não é a criação fora do logos, mas criação dentro dele: "Tudo foi gerado por ele, e sem ele nada foi gerado, e aquilo que foi gerado nele era a vida, e a vida era a luz dos homens" (p. 104). Os comentários de Tolemeo e Orígenes à passagem modificada do texto joanino levam Agamben à seguinte síntese da relação linguagem-vida que ali se manifesta: "a vida é aquilo que se gera na palavra e nela permanece inseparável e íntima” (p. 105). Segundo o filósofo, essa mudança de sentido se expressaria na reinterpretação agostiniana da inventio da retórica antiga e, posteriormente, no modo como os trovadores "conceberam a sua relação com o vivido" (p. 105). 
Contrariando uma concepção da ratio inveniendi (ou ars inveniendi, "arte da invenção") na retórica romana como técnica de buscar, na memória, os "lugares da palavra" - isto é, as expressões, temas e argumentos adequados ao discurso do orador ou à criação do poeta -, Santo Agostinho verá, segundo afirma Agamben, a descoberta do lugar da palavra (a inventio) como fruto de um "desejo amoroso" e o evento de linguagem "como um cruzamento inextricável de amor, palavra e conhecimento" (p. 105-106). O que era o automatismo da técnica mnemônica transforma-se, então, em "desejo amoroso", em uma entrega do criador à palavra. E é na esteira da interpretação agostiniana - continua o filósofo - que os poetas provençais formulam, no século XII, a sua interpretação da ratio inveniendi e abrem caminho ao desenvolvimento da lírica moderna:

A ratio inveniendi torna-se, para os poetas, a razo de trobar, e eles retiram dessa expressão o seu nome (trobador e trobaritz). A nova experiência da palavra aqui em questão remonta de modo decisivo para além da inventio clássica: os trovadores não querem recordar argumentos já consignados a um topos, mas querem sobretudo fazer experiência do evento mesmo da linguagem como topos original, que tem lugar em uma inextricável proximidade entre amor, palavra e conhecimento. A razo, que fundamenta a poesia e constitui aquilo que os poetas chamam o ditado (dictamen), não é desse modo nem um evento biográfico nem um evento linguístico, mas, por assim dizer, uma zona de indiferença entre vivido e poetado, um "viver a palavra" enquanto inexaurível experiência amorosa. Amor é o nome que os trovadores dão a essa experiência da demora da palavra no princípio, e, portanto, amor é para eles a razo de trobar, por excelência (p. 106).

Aquilo para onde remonta a "experiência da palavra como topos original” não parece ser outra coisa que o logos joanino no qual a vida é gerada. Mas, aqui, a vida parece se gerar na palavra na mesma medida em que a palavra se gera na vida, pois a razo de trobar, o fundamento originário (ou o ditado) da poesia trovadoresca, não é "nem um evento biográfico nem um evento linguístico", mas uma "zona de indiferença entre o vivido e o poetado". Quando, nos séculos XIII e XIV, são escritas as primeiras biografias dos trovadores, essa razo de trobar parece deslizar definitivamente para a esfera do vivido - uma vez que os eventos biográficos são revelados como a origem das poesias - e afastar-se do estatuto primordial do logos teológico. Mas o que ocorre aí de fato não é, segundo Agamben, senão o procedimento trovadoresco levado às suas últimas consequências. Tomando como exemplo a descrição da razo da canção de Bernart de Ventaron, Quan vei la lauzeta mover, o filósofo observa que o autor da razo:

[...] no intento aparente de referir-se à anedota biográfica que deveria explicar a poesia, ele a inventa inteiramente (e, na verdade, desajeitadamente) a partir dos primeiros três versos da canção [...]. Ele, portanto, constrói o vivido a partir do poetado e não vice-versa (como deveria acontecer segundo o paradigma biográfico com o qual nós, modernos, estamos acostumados) (p. 107).

Essa invenção da vida a partir da poesia que caracteriza tais biografias vai ao encontro de uma das "categorias italianas" que vemos Agamben evocar na coletânea da qual o Ditado da Poesia faz parte: a concepção dantesca da vida enquanto fábula, isto é, como "algo que tem a ver essencialmente com a palavra" (p. 108). Assim, aquilo que, "no prólogo de João, era demora inseparável da vida no logos torna-se agora fábula, comédia, vida-na-palavra” (p. 8). Para o filósofo, a postura de Dante aponta para um questionamento da legitimidade de um estatuto ôntico de vida, como algo que exista por si (mesmo que seja dentro da eternidade própria do logos divino): a vida dantesca só existe no gesto de linguagem 
humano (singular e circunstancial) que a cria - a poesia. Daí a vida ser na palavra e apenas nela. Precisamente essa exacerbação e essa humanização do vínculo palavra-vida Agamben verá no poeta italiano Antonio Delfini, de cuja obra-vivida o filósofo tratará no restante de seu ensaio.

Delfini escreveu em 1956 a própria razo na introdução à segunda edição de seu Il recordo dela Basca, e, como observa Agamben, ela se mostra, da mesma maneira que nas biografias provençais, como uma vida fabulada. Pois, em Delfini, a "indeterminação entre vivido e poetado é tão absoluta que a vida é verdadeiramente apenas o que se gera na palavra" (p.108, grifo do autor). Agamben mostra que a "vida real", fora da poesia, parece mesmo carecer, aos olhos do poeta, de qualquer valor e que a intenção de identificar o "real" fundamento vivido da arte é percebida por ele como mesquinhez e relegada aos que são incapazes de viver-na-palavra e, ao mesmo tempo, não deixam que se viva nela. Contra a "acusação psicológica" segundo a qual os homens se empenham incessantemente em criar justificativas a posteriori para consolidar a contingência de suas vidas, Delfini afirma, numa crítica salutar ao conceito de ilusão biográfica de Pierre Bordieu, que o "homem erige sua vida sobre as próprias justificações", pois "ninguém aqui cria mais do que a sua possibilidade de vida espiritual” (p. 109). E a justificação de Delfini não é outra senão a sua própria obra.

O fato de um poeta que vê na palavra a gênese da vida e do mundo ter escrito Poesie dela fine del mondo é o que intriga Agamben na última parte do ensaio. Como entender que a palavra criadora seja exatamente a mesma que põe fim à criação? A experiência poética na qual Delfini se lança nessas poesias é, segundo o filósofo, a da morte da razo de poetar, o fim da união entre a vida e a palavra: a escrita que se torna simplesmente literatura pela ausência da vida, e esta, que, "extraída à força da caneta e da palavra, inverte-se agora em vida nua, símbolo horrível e obscuro ‘da fraude, da traição, do pecado”” (p, 111, grifo meu). Por tal abandono da vida (a sua inclusão fora da poesia), Delfini, contudo, não se deixa vencer: as Poesie dela fine del mondo constituem também um protesto contra a inelutável morte da razo. Se o poeta se obriga a escrever a má poesia (a poesia apartada da vida), também não deixa de apontar para a "cifra luminosa da vida integral: a criança com a rosa inflamada, filha, naturalmente, de Guido Cavalcante (que aqui representa com autoridade a tradição dos poetas de amor)” (p. 112). A redenção no fim do mundo, o afloramento incontido da vida-na-palavra no momento mesmo da morte da vida e da palavra, representa, para o autor da Comunidade que vem, "a experiência, talvez única neste século, de um poeta que não pode aceitar que o seu vivido se torne biografia, que ele exista inexoravelmente fora da palavra como um fato real" (p. 112-113, grifo do autor).

Agamben vê na vida-obra de Delfini a experiência de um ditado poético na qual a vida é integralmente poesia, na qual a opacidade de uma vida enquanto coisa no mundo, enquanto "ente" (enquanto vida nua), desapareceu sem deixar rastros, e cuja fruição, por isso mesmo, "está reservada às gerações poéticas futuras" (p. 113) - quiçá aos integrantes da comunidade que se anuncia pela obra do filósofo. Delfini parece reformular, em toda a sua sugestão, o questionamento dantesco de um estatuto ôntico da vida.

\section{Vida real como vida nua, vida poetada como forma-de-vida}

Neste ponto final que conclui na mesma medida em que abre a porta às discussões vindouras, temos a nítida impressão de que a arqueologia empreendida por Agamben nesse ensaio reveste-se de um sentido mais amplo do que aquele de situar Delfini na tradição clássica da literatura italiana e fornecer uma chave de leitura à obra do poeta. No Ditado da poesia, assim como em todos os textos reunidos na coletânea Categorias italianas, alguns 
dos problemas filosóficos que mais ocupam o pensamento do autor parecem compor o solo sobre o qual ele desenvolve suas discussões. Arriscaria afirmar que o que move esses escritos é, em alguma medida, a tentativa agambeniana de produzir um conhecimento em que finalmente se aproximem a palavra que "possui o seu objeto sem o conhecer" (a poesia) e aquela que "conhece o seu objeto sem o possuir" (a filosofia) - tentativa que vemos anunciada, pela primeira vez, nas palavras finais de Estâncias (AGAMBEN,[1977] 2007a).

Nesse sentido, a expressão "vida nua" que Agamben utiliza para se referir ao que resta da vida após a sua separação da palavra não é mera coincidência: ela evidencia que o que está em jogo no Ditado da Poesia ou, de maneira mais ampla, na discussão acerca da relação arte-vida, é a possibilidade política de uma vida integral, isto é, de uma "forma-de-vida”, conceito que o filósofo contrapõe, em outros escritos, à fratura entre o substrato opaco da vida humana (a vida biológica) e as diversas formas de viver do homem contemporâneo. Fratura que, segundo sua visão, está na base da política no Ocidente.

No primeiro livro da série Homo sacer ([1996] 2007b), Agamben procura mostrar que o fundamento primeiro da política ocidental é a vida nua, isto é, a vida em sua opacidade ôntica, desprovida de conteúdo propriamente humano. Vida nua é vida do homem enquanto ser vivente (zoé) quando ingressa, descolada da vida qualificada do homem enquanto ser político (bios), na esfera da polis. Segundo Anne de Boever (2011, p. 30), a vida nua:

\begin{abstract}
Não é nem zoé nem bios. Ao contrário, é a vida que é produzida sempre que zoé é separada de bios, e bios (vida ética e política) põe em questão zoé (vida biológica). Seguindo as análises de Michel Foucault e Hannah Arendt, Agamben argumenta que os tempos modernos progressivamente reduzem os seres humanos à vida nua, uma vida que não é nem humana, nem animal, mas, ao contrário, um tipo inumano de vida que existe no limite das categorias éticas e políticas.
\end{abstract}

Esta é a vida opaca que, no Ocidente, aparece, desde o século XVII, como o maior "bem” da humanidade e cuja preservação caberia aos detentores do poder soberano. Entretanto, como observa Agamben, essa “preservação” é o eufemismo do qual a filosofia política clássica se vale para justificar a sujeição completa dos cidadãos à iminência da morte com a qual esse poder constantemente os ameaça. A insegurança da vida dos homens no estado de natureza hobbesiano - onde nada impediria que, em meio a conflitos de interesse, a violência de uns fosse exercida sobre os outros e vice-versa - é substituída pela "segurança" advinda do soberano, que concentra em si o direito de vida e de morte sobre todos os cidadãos e, em tal posição, estabelece os diversos dispositivos de controle (o ordenamento jurídico, a polícia, etc.) por meio dos quais se mantém uma determinada ordem social. A barreira contra a violência individual generalizada é, assim, a sujeição à violência de exceção, a violência do soberano que institui as regras de convivência na polis, às quais todos devem irrevogavelmente obedecer. O que institui esse estado de coisas é precisamente aquela "vida" sem atributos que "precisa" ser preservada, isto é, uma vida enquanto coisa, descolada do gesto humano, que entra na arena política, ironicamente, como o "bem maior" em torno do qual se deve instituir as regras de convivência. Esta é a vida nua, que, por não ser vida própria de ninguém, pode ser, de acordo com o que deseja o soberano, matada sem qualquer punição.

No século XX, tal política toma a forma de um "estado de exceção permanente", no qual o exercício do direito de vida e de morte do soberano (ou da lei que ele institui) é constante, a matabilidade da vida se nos apresenta da maneira mais clara, e "a vida nua, que era o fundamento oculto da soberania, tornou-se por toda parte a forma de vida dominante" (AGAMBEN, [1996] 2015, p. 16). 
A vida, no estado de exceção tornado normal, é a vida nua que separa em todos os âmbitos as formas de vida de sua coesão em uma forma-de-vida. Ầ cisão marxiana entre o homem e o cidadão sucede, assim, aquela entre a vida nua, portadora última da opacidade da soberania, e as múltiplas formas de vida abstratamente recodificadas em pessoas jurídico-sociais (o eleitor, o trabalhador dependente, o jornalista, o estudante, mas também o soropositivo, o travesti, a estrela pornô, o idoso, o progenitor, a mulher), que repousam todas nela (AGAMBEN,,[1996] 2015, p. 16).

Nesse contexto, a vida biológica aparece como versão secularizada da vida nua, compartilhando as características de "indecidibilidade" (que é afinal a vida nua senão o não ser zoé do homem e ao mesmo tempo o seu não ser bios? E que fundamento justo, científico, ético ou político poderia assegurar a decisão sobre qual vida é própria de se viver e qual vida pode ser matada?) e "impenetrabilidade" (opacidade, o nada que é a substância da vida enquanto coisa). O controle da lei sobre os corpos da população (sobre sua "saúde") - que atinge o seu ponto culminante na manutenção, pela medicina, da vida vegetativa em algumas situações (a negação do direito de morte do indivíduo sobre si mesmo) - é prova máxima de que a vida biológica constitui, hoje, "as formas de vida reais em formas de sobrevivência” (AGAMBEN,[1996] 2015, p. 18, grifo do autor).

O léxico jurídico-social de formas de vida (formas identitárias preestabelecidas ou “formas de sobrevivência”) é, antes de tudo, uma maneira de coisificar a existência do homem e classificá-la, controlá-la: enquanto duas entidades separadas, o homem e seu substrato biológico não se fundem, e a vida nua, matável, está sempre visível. Contra essa cisão, Agamben apresenta o conceito de forma-de-vida: "uma vida para a qual, no seu modo de viver, está em jogo o próprio viver e, no seu viver, está em jogo antes de tudo o seu modo de viver”; na qual "jamais é possível isolar algo como uma vida nua” (AGAMBEN, [1996] 2015, p. 13-14). Para o filósofo, o homem coeso em sua forma-de-vida faz constantemente a experiência de seu ser em potência, isto é, de sua completa abertura à possibilidade de fazer-se singular em cada gesto e não sucumbir a uma forma identitária preestabelecida e, assim, ao controle de um poder soberano. A forma-de-vida é o par antitético do homem autômato sob tutela do Estado ou da lei, do homem que aparece socialmente apenas já em ato ("o eleitor, o trabalhador dependente, o jornalista”) e que repousa sobre a opacidade do substrato biopolítico da vida nua.

Quem faz a experiência de sua potência é, para Agamben, aquele que faz, antes de tudo, a experiência do próprio pensamento, pois o ser do pensamento é, como o filósofo afirma ao resgatar os escritos de Aristóteles, a pura potência. "A intelectualidade e o pensamento não são uma forma de vida ao lado de outras nas quais se articulam a vida e a produção social, mas são a potência unitária que constitui em formas-de-vida as múltiplas formas de vida". É ao pensar em si mesmo, ao refletir sobre a possibilidade de ser e de não ser, que os homens assumem, em seus gestos, a forma coesa de uma forma-de-vida. Eis aí o único meio de o homem viver a sua liberdade e construir a própria felicidade, escapando ao controle de um poder soberano. Eis por que a forma-de-vida "deve tornar-se o conceito-guia e o centro unitário da política que vem” (AGAMBEN, [1996] 2015, p. 21).

É precisamente uma vida que em cada gesto põe em jogo o seu modo de viver, uma vida completamente mergulhada em sua forma de viver, que Agamben parece encontrar em Delfini (a vida que se faz na poesia e não existe fora dela) e cujas cifras já podiam ser percebidas nos poetas provençais e estilonovistas. Não se deixar ler como uma "vida real", lutar pela coesão legítima entre gesto e vida, esse é o sentido da fábula de Delfini. Não se trata apenas de uma atitude poética: é uma atitude política, é a afirmação de uma singularidade-vivida que não se sujeita ao indiscriminado exercício do poder de vida e morte do sobera- 
no e/ou da Lei (sua morte é um crime), pois não é coisa - é ser, é humano. É também essa coesão entre vida e forma de vida o que perseguiu o compositor Heitor Villa-Lobos, e é essa busca que se vê registrada em sua biografia.

\section{A fábula de Villa-Lobos: uma forma-de-vida}

Na introdução à reedição de 1983 de seu livro sobre Villa-Lobos (Heitor Villa-Lobos: compositor brasileiro), o musicólogo e diplomata Vasco Mariz salienta a imaturidade que caracteriza a primeira versão desse trabalho de juventude: era difícil para ele, naquela época (fins da década de 1940), não ceder aos conselhos de amigos e às instruções do próprio biografado acerca de quais fatos deveriam ser narrados e de que maneira seria construída a própria narrativa. Mariz queixa-se, especialmente, da "profunda impressão" que suas entrevistas com Villa-Lobos - fontes das primeiras e mais significativas informações sobre o compositor que constam no livro - lhe causaram, e relata que, "para não parecer dominado pela personalidade gigantesca do biografado", procurou "qualificar os elogios e ou até agravar restrições" (MARIZ, 1983, p. 9).

Tenha sido o empenho do biógrafo insuficiente ou a personalidade de Villa-Lobos demasiadamente impressionante, o fato é que, como bem observou Paulo Guérios (2009), o livro saiu quase uma autobiografia: ali, a voz de Mariz aparece menos como a do historiador ou musicólogo empenhado em resgatar os fatos reais da vida do músico, do que como a do contador apaixonado da fábula que Villa-Lobos ditara. E, seguindo o mesmo procedimento que acima vimos originar as biografias provençais e a razo de Delfini, essa fábula é o retrato de uma vida criada a partir da música, uma vida verdadeiramente musicada. Mas aqui o que é musicado reveste-se de uma importância simbólica ainda mais ampla. Pois, aquilo que nele se quer pronunciar é a ideia-guia das reflexões de intelectuais, políticos e artistas brasileiros entre as décadas de 1920 e 1950, período em que Villa-Lobos se impõe como figura máxima da cena da música erudita no Brasil: trata-se da ideia de brasilidade, de identidade nacional brasileira, que, com justiça, nossos críticos literários, musicólogos, historiadores e sociólogos poderiam chamar de "categoria brasileira" por excelência. Digo isto tendo vista o fato de a que preocupação de intelectuais e artistas brasileiros com o tema da identidade nacional marca fortemente o desenvolvimento da cultura letrada brasileira desde a segunda metade do século XIX até, pelo menos, a década de 1960. O indianismo na literatura romântica e na música de Carlos Gomes e Nepomuceno, o pensamento social brasileiro de Sílvio Romero e Euclides da Cunha a Gilberto Freyre e Sérgio Buarque de Holanda, o naturalismo e as três "gerações" modernistas na literatura do período republicano, a música erudita de Nepomuceno e Villa-Lobos a Guerra-Peixe, a invenção da tradição do samba e seus desenvolvimentos, as realizações da Era Vargas e seu suporte à ascensão do samba, nossa crítica literária anterior a Antonio Candido (e, talvez, até mesmo a de Candido), a musicologia de Mário de Andrade a Bruno Kiefer - em todos esses fenômenos, e nas ideias de pessoas tão importantes e influentes como essas, a brasilidade, como identidade cultural (ou racial nos mais antigos), aparece, em maior ou menor medida, como categoria heurística operante. Isto, com efeito, já foi afirmado, no que diz respeito à música erudita, à musicologia e ao samba, por autores como Pereira (2007), Lima (2017b), Contier (1988), Fernandes (2010), Braga (2002); quanto ao pensamento social brasileiro, por Ortiz (2012), Mota (1974), Leite (1969), Souza (2015), e, quanto à literatura e à crítica literária, por Lima (1998) e Schwarz (1999).

Mas, voltando a Villa-Lobos, pesquisas recentes têm mostrado que, até o final da década de 1910, sua produção não seguia um projeto artístico definido, que fosse anunciado 
com um “manifesto”, ou algo que o valha. Suas incursões pelos estilos de Wagner, Liszt, pelo pós-romantismo francês e pelo modernismo de Debussy tinham, talvez, um objetivo tão prático quanto artístico, embora delas surgissem já um modo bastante original de compor e algumas das pérolas pianísticas villa-lobianas mais conhecidas: as Danças Características Africanas e a Prole do Bebê n. 1. O objetivo prático a que me refiro é o de mostrar-se, aos olhos do público, da crítica e dos remanescentes da geração de compositores já consagrados que o precedeu (Alberto Nepomuceno e Henrique Oswald) que ele dominava as vertentes musicais hegemônicas e estava atualizado quanto às novas tendências - ele precisava e queria mostrar-se um compositor erudito.

De fato, a música não existe sem alguém que a execute, sem um público que se disponha a ouvi-la, e nenhum compositor poderá fazer carreira sem o respaldo de seus pares, sem instrumentistas que comprem suas ideias, sem o aplauso da plateia e sem o dinheiro das entradas. Villa-Lobos, como artista em início de jornada, precisava conquistar esses pré-requisitos, dialogar com as expectativas do meio, dominar a tradição e, partindo dela, mostrar-se novo, até o ponto em que pudesse criar ele mesmo novas expectativas. Com efeito, Villa-Lobos acreditava que seu talento e sua ousadia iriam além do já conhecido e que seu destino era a universalidade. Em O imprevisto, uma reflexão filosófico-biográfica datada de 1907 (VILLA-LOBOS, 1920a), ele expressa essa convicção, ao negar-se a pertencer aos "vultos, massas e coisas que se equilibram na atração mútua da própria gravidade (pretendentes talvez a imagens, seres, e almas)”: ele se via como um "espírito fugitivo”, cujo destino era ser "imortal".

A afirmação de singularidade foi uma obsessão em Villa-Lobos. Em uma entrevista concedida ao jornal carioca $A$ noticia, em setembro de 1920, ao revelar a pesquisa que, segundo ele, deu origem a seu tríplice projeto sinfônico inspirado na Primeira Guerra Mundial - Guerra, vitória e paz -, o compositor enfatiza, a um só tempo, a necessidade de equiparar-se à tradição e o desejo de provar-se um inovador.

Colhendo dados e notas nos livros históricos, confrontando as situações dos tempos, através de sua evolução, observando meticulosamente os pontos mais lógicos, as épocas artísticas, os povos civilizados, etc. Ao cabo dessas minuciosas observações, concluí meu trabalho musical. [...] A minha inspiração [...] é resultado tão somente de minha nevrose, sem a mínima influência [...] deste ou daquele compositor (VILLA-LOBOS, 1920b).

Eis o erudito, estudioso das "épocas artísticas”, sobre cujo estilo, entretanto, "nenhuma” delas influi: a tradição no bolso e a originalidade à vista. Villa-Lobos repete esse discurso todas as vezes que lhe surge a oportunidade de falar sobre si mesmo. O domínio da tradição foi para ele, ao longo de toda a sua carreira, um parêntese necessário (e inegavelmente audível) aos possíveis apreciadores da "singularidade qualquer" de sua música.

Mas a obsessão villa-lobiana pela originalidade só encontra o suporte de um projeto artístico manifesto e ele só se torna definitivamente um promotor de novas tendências (a princípio, bastante marginais) no meio musical brasileiro após participar da Semana de Arte Moderna (quando inicia o seu diálogo com os jovens intelectuais paulistas sedentos de modernidade artística à la brasileira) e após confrontar-se, em 1923, com o cenário artístico parisiense. Tanto nos debates sobre música erudita brasileira que se seguiram à Semana nos quais Mário de Andrade e Renato Almeida começavam a se destacar - quanto no desejo pelo "exótico" que dominava o ambiente musical europeu dos anos 1920, Villa-Lobos se vê em face da nova e definitiva vereda de sua vida-obra: a música nacional, isto é, uma música em que se combinavam técnicas composicionais da música erudita ocidental, aspectos da 
música popular brasileira e um “imaginário sonoro tropical”.

Desse momento em diante, todas as obras compostas por Villa-Lobos têm como razo explícita a sua imersão no "Brasil musical" imaginado por ele, pelos demais compositores que despontam nesse tempo (Luciano Gallet, Lorenzo Fernández, Francisco Mignone) e por intelectuais modernistas como Mário de Andrade e Renato Almeida. É o Brasil da música folclórica, sertaneja, nordestina e de algumas manifestações culturais urbanas que a intelligentsia da música nacional entendia como folclore: a modinha, o maxixe, o choro, o samba (CONTIER, 1988). Para Villa-Lobos, é também o Brasil da natureza exuberante, do índio "primitivo", das lendas amazônicas. Esse é o "programa” sobre o qual o compositor erige, na década de 1920, a sua famosa musicalmente complexa série de Choros, as Cirandas, o Noneto, o Trio para oboé, clarinete e fagote. Da década de 1930 em diante, a complexidade da textura dos Choros dá lugar a obras neoclássicas, tecnicamente menos audaciosas, mas nem por isso, menos efetivas ou inspiradas no Brasil imaginado. As mais famosas estão reunidas em torno da série de Bachianas Brasileiras que, como anuncia o próprio título, pretendem fazer cantar juntas as vozes do ídolo alemão e da "autêntica" música popular brasileira.

A brasilidade de que se reveste a música de Villa-Lobos também passa a habitar, nesse contexto, o modo como ele via a sua vida. Da entrega do compositor à sua obra surge a fábula brasílica e musicada de sua vida. Dois anos após voltar de sua primeira viagem a Paris (1925), numa entrevista ao jornal Correio da Manhã, Villa-Lobos já se mostrava um pesquisador e profundo conhecedor da música popular brasileira, mestre e professor na arte de torná-la "universal” por meio de técnicas eruditas modernas e compatíveis com a matéria-prima da música nacional. Segundo o compositor, a música europeia recebeu aqui a "influência do meio" e do "caldeamento do sangue":

[...] e se fez música popular, cujo ritmo inconfundível é de uma incomparável riqueza. Com esse ritmo é que se há de criar a nossa música, mas é preciso que o tomemos em sua essência, para revelá-lo, para traduzi-lo pela emoção criadora que o universalizará. O essencial, porém, é não o estilizar, não fazê-lo "leit motiv" de uma composição clássica enquadrando-o nos moldes conhecidos dos outros povos. Precisamos tratá-lo como elemento próprio e fundamental e não como detalhe pitoresco (VILLA-LOBOS, 1925).

No final da década de 1920, em sua segunda viagem à capital francesa, o conhecimento "teórico" da "música do povo" do Brasil e do modo correto de universalizá-la ganha bases empíricas extraordinárias. Ali, além de apresentar com sucesso de público e de crítica algumas de suas principais obras, o compositor aparece à imprensa parisiense como o aventureiro à brasileira que os leitores europeus curiosos desejariam conhecer e que ele mesmo incorpora, imergindo "xamanicamente" numa perspectiva indígena-branqueada por meio dos cantos, dos ritmos, da energia ritualística monumental de alguns de seus Choros. Não é senão essa imersão que faz Villa-Lobos contar aos jornais franceses as histórias das viagens que ele teria realizado pelo interior do Brasil, em meio à mata virgem, navegando pelos rios da Bacia Amazônica, encontrando "índios selvagens" e anotando todas as particularidades musicais desse mundo para aproveitá-las em suas composições. Quem ouve pela primeira vez Choros n. 10, logo percebe que a fábula de Villa-Lobos é, como na descrição da razo da citada canção de Bernart, inventada "desajeitadamente” a partir da música.

Para Villa-Lobos, era tão difícil conceber a sua vida apartada de seu projeto artístico nacional que ele se dispõe a recompor algumas de suas obras anteriores à década de 1920, de modo a inseri-las em tal projeto. É assim que os poemas sinfônicos de argumentos 
gregos Tédio da Alvorada e Myremis tornam-se Uirapuru e Amazonas e ganham argumentos amazônicos. As peças mudam, mas suas primeiras datas de composição são conscientemente mantidas em 1917: ocorre aí uma verdadeira operação do passado, um ajuste de contas com o vivido a partir do musicado, similar ao que ocorre, como mostra um artigo recente, com o primeiro movimento da Suíte Popular Brasileira.

Quando, no final da década de 1940, Vasco Mariz começa a redigir a mencionada biografia, Villa-Lobos vivia já, completamente, em sua fábula e tratava de popularizá-la mundo afora nas viagens que realizava sob os auspícios do Itamaraty. A atuação do compositor no projeto de educação musical e na organização das demonstrações orfeônicas durante a Era Vargas foi premiada com um suporte político sem precedentes ao desenvolvimento de sua carreira e com a aproximação decisiva entre sua (auto) imagem (musicada) e a ideia de brasilidade com a qual o governo daquele tempo pretendia unir o país (CONTIER, 1998; LIMA, 2017b). Nesse tempo, Villa-Lobos e sua música começam a morar, juntos, na constelação de símbolos que compõem o imaginário nacional e, é assim, enquanto símbolo da nação, que ele se vê e se mostra no Brasil e alhures, em suas viagens.

Esse é o contexto em que surge a biografia escrita por Mariz, esse é o fabuloso compositor cuja vida musicada e brasilizada será descrita nas páginas do livro. O processo de aquisição do "espírito" musical brasileiro e o desenvolvimento da genialidade "inata" de Villa-Lobos são apresentados, na narrativa, como o rápido e inelutável cumprimento de um destino. Entre 1887, ano de nascimento do compositor, e 1915, ano em que pela primeira vez apresenta publicamente uma obra orquestral de sua autoria, a sua "personalidade" artístico-brasileira aparece, aos olhos do biógrafo e do biografado, de uma vez por todas consumada, e todos os eventos posteriores a tal consumação constituem marcos nas veredas por meio das quais a personalidade -musicada do artista se fez vida e música.

E quais as etapas pelas quais passou o processo de consolidação dessa incomum personalidade? (1) A iniciação precoce e o rápido desenvolvimento de Villa-Lobos na música erudita, para o que contribuiu decisivamente o seu pai e primeiro professor de música, Raul Villa-Lobos; (2) a força sobrenatural da predestinação, que o fez, dentre todos os seus irmãos, o preferido de seu pai; (3) o gênio inato e inexplicável, que o fez distinguir por conta própria, ainda quando criança, as variedades musicais que mais o interessavam e guardar tais preferências para sempre no subconsciente: a "música rural, sertaneja" e a polifonia de Bach (eis a origem fabulada das Bachianas brasileiras); (4) a oportunidade de conhecer, ainda menino, "todos os gêneros musicais do Nordeste" nos salões cariocas do fim do século XIX, que ele e o pai frequentavam; (5) o fascínio que cedo despertou nele a "música popular", a contragosto da família, fascínio que o acompanharia por toda a vida; (6) a convivência e a amizade travada na juventude com alguns dos praticantes dessa música popular, os "chorões", em meio aos quais "formou uma faceta de sua personalidade" (eis o vivido gerado nos Choros); (7) o "espírito liberto" que sempre o fez fugir à banalidade e jamais se adequar às cartilhas de escolas de música; (8) e, por fim, as peregrinações pelo interior do país (aquelas que o compositor anuncia em sua segunda viagem a Paris), nas quais terminou de despertar o "sentido de brasilidade que trazia no sangue" e coletou o "riquíssimo" material folclórico que viria morar no cerne de sua produção artística (MARIZ, 1983, p. 23-38).

\section{Conclusão}

Como foi dito no início deste trabalho, essa vida, a vida que Villa-Lobos criou em sua música, é, talvez, o único registro que a musicologia brasileira nos oferece de uma tentativa de conciliar, sem frestas, vida e obra. É também essa a vida que as pesquisas recen- 
tes sobre o compositor pretendem subtrair à fábula e tornar real, mostrando as contradições que nela se escondem e o substrato político-ideológico que participa de sua invenção. De fato, essa é uma tarefa a qual sociólogos, historiadores e antropólogos não podem se furtar, mas me parece que nenhuma análise desse tema fará justiça à sua humanidade se não enxergar na fábula algo além de propaganda e ideologia.

O fato de que Villa-Lobos inventava histórias mirabolantes e "acabava acreditando nelas” é bastante conhecido e foi afirmado pelo próprio Vasco Mariz, quando tentava reconhecer e atenuar os "exageros" da primeira versão de seu livro. Essa sinceridade da invenção é reflexo da imersão do compositor em sua atividade criadora, é sinal de que a música era, como ele mesmo afirmou tantas vezes, a razo de sua existência, de sua singularidade. Mesmo quando cedia à exigência de mostrar-se conhecedor da tradição musical do Ocidente, Villa-Lobos não deixava de afirmar essa singularidade - se dizia conhecer o cânone, jamais confessava submeter-se a ele. Sua autoidentificação com a nação só fazia sentido na medida em que isso confirmava tal singularidade: ele não acreditava ser "mais um" compositor nacional, mas o primeiro, e único, inigualável, inclassificável, incontrolável, irreconhecível por qualquer rótulo identitário sob o qual se vislumbrasse a opacidade de uma vida nua. Em sua música, e apenas nela, deveria ser buscado o seu modo-de-ser, que, por razões históricas, repousou sobre a ideia de brasilidade. Não uma brasilidade padrão, ou forjada por Andrades ou Freyres, mas uma fábula villa-lobiana de brasilidade.

Creio que, como Delfini, Villa-Lobos constitui talvez o único exemplo de um compositor do novecentos que não podia conceber a sua vida senão como uma forma-de-vida, como uma vida integral. E para nós, que vivemos a fratura das formas de vida atuais, esse personagem sinaliza para a possibilidade de superar essa cisão, e parece abrir caminho para a experiência artística da "comunidade que vem”. Não é como grande símbolo da nação que Villa-Lobos par lui même deve desbaratar as críticas, mas como índice claro de que a busca da felicidade, que Agamben lembra ser o fim último da filosofia, é a experiência humana mais própria e sempre possível. Quem sabe esteja aí o porquê do modo como Bartolomeu Wiese definiu Villa-Lobos, no cinquentenário de sua morte: "um antigo deus mitológico - travesso e carinhoso - que nos mandaram para voltarmos a acreditar na alegria" (WIESE, 2009, p. 24).

\section{Notas}

1 Almeida (1926; 1942); Andrade ([1939] 1975; [1929] 1987); Azevedo (1956), Mariz (1981) e Kiefer (1977). Esses trabalhos são analisados em maior detalhe no capítulo 2 de minha dissertação (LIMA, 2017b).

2 Ver, por exemplo, Guérios (2009) e Chernavsky (2003).

3 Na dissertação de mestrado recentemente concluída (LIMA, 2017b), aproximei-me deste tema pelo viés da crítica, vinculando a redação da biografia ao momento histórico, político e ideológico em que ela surge.

4 A partir deste momento, farei repetidas menções ao ensaio de Agamben (2014). Indicarei apenas o número da página da qual retiro as citações. As referências completas voltarão a figurar no texto quando minhas reflexões se estenderem a outras obras do autor.

5 A palavra "moderno (a)" adquire no texto de Agamben, que ora analisamos, um sentido de "contemporaneidade” e nos remete à sociedade e à cultura ocidentais do século XX. No Homo Sacer I ([AGAMBEN, 2007b, p. 117), "modernidade" parece ter um sentido epocal, delimitando, na história do Ocidente, um período que vai, aproximadamente, das Luzes (século XVIII) à contemporaneidade, e que é marcado pelo fato de que, nele, "a vida se coloca sempre mais claramente no centro da política estatal”.

${ }_{6}$ Fato para o qual Agamben chama a atenção de seus leitores na parte final de Estâncias ([1977] 2007a).

7 É o que Agamben afirmará no âmbito da filosofia política em suas investigações acerca do juramento no Homo sacer II: o sacramento da linguagem ([2006] 2008).

8 Trata-se da busca das origens e das transformações dos temas filosóficos caros ao autor, busca que ele empreende ao longo de toda a sua obra. 
9 Ver, também de Agamben, O que é contemporâneo e outros ensaios (2009).

${ }^{10}$ A relação sugerida entre as experiências trovadoresca e moderna (Agamben parece estar pensando, aí, em Baudelaire e no que se segue a ele, chegando, enfim, a Delfini, que é o personagem principal do ensaio) da palavra não é menos complexa do que instigante. Apenas uma análise minuciosa dessas duas tradições poderia esclarecê-la em todas as suas implicações, tarefa que foge às minhas possibilidades e ao escopo deste trabalho. Contento-me, nas páginas subsequentes, em estudar a potência política que, para o filósofo, parece morar em tais experiências.

11 "Modernismo" e "modernidade" são utilizados, neste momento do texto, como categorias com as quais a historiografia e a crítica de arte (de música, especialmente) do século XX procuraram caracterizar as inovações técnicas e estéticas ocorridas, defendidas e combatidas entre o fim do século XIX e a primeira metade do XX, no campo artístico ocidental. É também nesse sentido que os termos aparecerão mais à frente, relacionados ao movimento modernista brasileiro. Não tenho em vista, portanto, a modernidade na acepção epocal-política agambeniana, mencionada na nota de n. 5 .

12 Sobre isso, ver Lima (2017a).

${ }^{13}$ Esse texto de Villa-Lobos consta no programa do concerto de 30 de agosto de 1920, no Instituto Nacional de Música, em que seria executada a sua $1^{a}$ Sinfonia (1916). O programa, por sua vez, está sob a guarda do Museu Villa-Lobos.

14 Para discussões mais aprofundadas sobre a "guinada nacional” na trajetória de Villa-Lobos, ver Guérios (2009), Arcanjo Jr. (2013) e Damasceno (2007).

15 Obviamente, cada um desses personagens dava seu toque pessoal a tal imaginário brasílico musical, embora certos traços façam dele um fenômeno coletivo, como procura mostrar a tese de Contier (1988).

${ }^{16}$ É clara, aqui, minha referência irreverente ao perspectivismo ameríndio de Viveiros de Castro (2015).

17 No acervo do Museu Villa-Lobos, há uma série de recortes de jornal que registram as histórias contadas por Villa-Lobos em Paris e a repercussão delas na imprensa brasileira. Esse episódio já foi comentado por vários autores - o próprio Mariz (1981; 1983) e, também, Guérios (2009) são alguns deles.

18 Ver Lima (2016).

19 A comunidade anunciada por Agamben não "virá", mas vem. O tempo verbal presente indica o que o autor "profetiza" em vários de seus escritos: a vida integral, mesmo que atualmente esteja sendo ameaçava por todos os lados, está sempre aí em potência. Pode nãos ser a regra, mas é uma exceção redentora e possível. Ela é o oposto da exceção soberana que hoje virou regra. É a exceção legítima que deve se transformar na regra legítima para que a comunidade agambeniana já não venha, mas simplesmente seja por toda parte.

\section{Referências}

AGAMBEN, Giorgio. A comunidade que vem. Belo Horizonte: Autêntica Editora, 2013.

UFMG, 2007a.

. Estâncias: a palavra e o fantasma na cultura ocidental [1977]. Belo Horizonte: Editora

. Homo sacer I: o poder soberano e vida nua [1996]. Belo Horizonte: Editora UFMG, 2007b.

. Meios sem fim: notas sobre a política [1996]. Belo Horizonte: Autêntica, 2015.

. O ditado da poesia. In: . Categorias italianas: estudos de poética e literatura. Florianópolis: Editora UFSC, 2014.

. O que é contemporâneo e outros ensaios. Chapecó: Argos, 2009.

. O sacramento da linguagem: arqueologia do juramento (Homo sacer II, 3) [2008]. Belo Horizonte: Editora UFMG, 2011.

ALMEIDA, Renato. História da Música Brasileira. 1. ed. Rio de Janeiro: F. Briguiet, 1926. . História da Música Brasileira. 2. ed. Rio de Janeiro: F. Briguiet, 1942.

ANDRADE, Mário. Evolução Social da Música no Brasil. [1939]. In: Aspectos da música brasileira. São Paulo: Livraria Martins Editora, 1975.

. Pequena história da música. [1929]. Belo Horizonte: Editora Itatiaia Limitada, 1987. 
ARCANJO JR., Loque Arcanjo. Os sons de uma nação imaginada: as identidades musicais de Heitor Villa-Lobos. 2013. 221 f. Tese (Doutorado em História) - Faculdade de Filosofia e Ciências Humanas, Universidade Federal de Minas Gerais, Belo Horizonte, 2013.

AZEVEDO, Luiz Heitor Corrêa de. 150 anos de música no Brasil. Rio de Janeiro: José Olympio, 1956.

BOEVER, A. de. Bare life. In: MURRAY, A.; WHYTE, J. (Ed.). The Agamben dictionary. Edinburgh: Edinburgh University Press, 2011. p. 30-31.

BRAGA, Luiz O. R. A invenção da música popular brasileira: de 1930 ao final do Estado Novo. 2002. Tese ( Doutorado) - Instituto de Filosofia e Ciências Sociais/Programa de Pós-Graduação em História Social, Universidade Federal do Rio de Janeiro, Rio de Janeiro, 2002.

BROMBERG, Carla. História da música no Brasil e musicologia: uma leitura preliminar. Projeto História, São Paulo, v. 43, p. 415-444, 2011.

CHERNAVSKY, A. Um maestro no gabinete: música e política no tempo de Villa-Lobos. 2003. 243 f. Dissertação (Mestrado) - Universidade Estadual de Campinas, Campinas, 2003.

CONTIER, Arnaldo D. Brasil Novo. Música, nação e modernidade: os anos 20 e 30. 1988. Tese (Livre-docência em História) - Faculdade de Filosofia, Letras e Ciências Humanas, Universidade de São Paulo, São Paulo, 1988.

DAMASCENO, André Álcman. Villa-Lobos: negociações simbólicas na formação da moderna música brasileira. 2007. Dissertação (Mestrado) - Programa de Pós-Graduação em SociologiaDepartamento de Sociologia, Centro de Humanidades, Universidade Federal do Ceará, Fortaleza, 2007.

FERNANDES, Dmitri Cerboncini. A Inteligência da Música Popular: a "autenticidade" no samba e no choro. 2010. $414 \mathrm{f}$. Tese (Doutorado em Sociologia) - Faculdade de Filosofia, Letras e Ciências Humanas, Programa de Pós-Graduação do Departamento de Sociologia, Universidade de São Paulo, São Paulo, 2010.

GUÉRIOS, Paulo Renato. Heitor Villa-Lobos: o caminho sinuoso da predestinação. Curitiba: Edição do Autor, 2009.

KIEFER, B. História da música brasileira: dos primórdios ao início do século XX. Porto Alegre: Movimento, 1977.

. Villa-Lobos e o modernismo no Brasil. Porto Alegre: Movimento, 1986.

LEITE, Dante. M. O caráter nacional brasileiro: História de uma ideologia. 2 ed. São Paulo: Pioneira, 1969.

LIMA, Luiz Costa. Concepção de história literária na "formação". In: D’INCAO, Maria A; SCARABÔTOLO, Eloísa F. (Org.). Dentro do texto, dentro da vida: ensaios sobre Antonio Candido. São Paulo: Cia das Letras, 1998.

LIMA, Lurian J. R. S. Mazurka-Choro na trajetória de Villa-Lobos: lembrança e ressignificação. Revista Vórtex, Curitiba, v. 4, n. 1, p. 1-25 2016.

. Villa-Lobos e a música popular: uma suíte “à brasileira”. Revista Vórtex, Curitiba, v. 5, n. 1, p. 1-22, 2017a.

. Suíte Popular Brasileira na trajetória de Villa Lobos: "arte”, "povo” e uma suíte "à brasileira”. 2017b. 211 f. Dissertação (Mestrado em Música) - Setor de Comunicação e Artes, Programa de Pós-Graduação em Música, Universidade Federal do Paraná, 2017b. 
MARIZ, Vasco. Heitor Villa-Lobos: compositor brasileiro. [1949]. Rio de Janeiro: Zahar, 1983. História da música no Brasil. Rio de Janeiro: Civilização Brasileira, 1981.

MOTA, Carlos. G. Ideologia da Cultura Brasileira: 1933-1974. São Paulo: Ática, 1974.

ORTIZ, Renato. Cultura brasileira e identidade nacional. [1985]. Taubaté: Editora Brasiliense, 2012.

PEREIRA, Avelino R. Música sociedade e política: Alberto Nepomuceno e a República Musical. Rio de Janeiro: Editora UFRJ, 2007.

SCHWARZ, Roberto. Os sete fôlegos de um livro. In: . Sequências brasileiras. São Paulo: Cia. das Letras, 1999.

SOUZA, Jessé. A tolice da inteligência brasileira: ou como o país se deixa manipular pela elite. São Paulo: LeYa, 2015.

VILLA-LOBOS, Heitor. Entrevista concedida. A notícia, Rio de janeiro, set. 1920a. Fonte: Museu Villa-Lobos, Recortes de Jornal, Livro 01.

. O imprevisto. In: Concerto Symphonico promovido pelo Instituto Nacional de Música, Rio de Janeiro 30 ago. 1920b. Programa de Concerto. Fonte: Museu Villa-Lobos, Programas de concerto.

. Podemos crear uma musica brasileira? Villa-Lobos, compositor, e Renato Almeida, crítico, respondem a essa pergunta do "Correio da Manhã". Correio da Manhã, Rio de Janeiro, 12 ago. 1925.

VIVEIROS DE CASTRO, E. Metafísicas canibais. São Paulo: Cosac Naify, 2015.

WIESE, B. Heitor Villa-Lobos: o demolidor índio de casaca. Em Pauta, v. 6, n. 24, p.291-301, dez. 2009.

Lurian José Reis da Silva Lima - Mestre em Música, na linha de pesquisa Musicologia/Etnomusicologia, pela Universidade Federal do Paraná (UFPR) e com bolsa da CAPES. Bacharel em violão pela Universidade Estadual do Paraná (UNESPAR) (Escola de Música e Belas Artes do Paraná). Licenciando em Música pela Faculdade de Artes do Paraná pela UNESPAR. É membro do Grupo de Pesquisa em Etnomusicologia da UFPR. 1 